\title{
CORRESPONDENCE
}

Correspondents are asked to be brief

Blood Donors and the Transfusion Service J. Darnborough, F.R.C.PATH., T. E. Cleghorn, F.R.C.P., F.R.C.PATH., and F. Stratton,

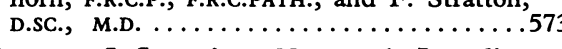

Factors Influencing Neonatal Jaundice O. B. Eden, M.B., and others; D. P. Davies, M.R.C.P., D.C.H., and C. R. Gomersall, M.R.C.o.G. .................573

Mycoplasma pneumoniae Infection

K. Lind, $M . D \ldots \ldots \ldots \ldots \ldots \ldots \ldots \ldots$

Death during Dentistry

M. W. P. Hudson, F.F.A.R.C.s. . . . . . . 574

Catecholamine Excretion Levels in Neuro-

blastoma
Jane V. Bond, F.F.R., D.C.H...........574

Age Limit for Contraceptives

Elizabeth M. Elliott, M.B...........574

Penicillamine and Creaking Joints

R. D. Sturrock, M.R.C.P., and P. M. Brooks,

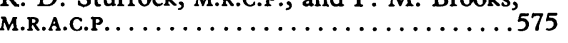

Assessment of Surgical Treatment

D. H. Spodick, M.D............... . 575

Halitosis

R. N. C. Smith, F.R.C.G.P. . . . . . . . . 575

Gonorrhoea in Obstetrics and Gynae-

cology
J. K. Oates, F.R.C.P.ED., and R. P. Sarkhel,

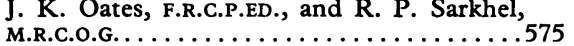

Progesterone Dermatitis

L. J. Hipkin, M.D....... . . . . . . 575

Unsuspected Opiate Overdose

B. W. Han cock, M.B............... 575

Expenses for Study Leave

P. Banks, M.B., F.D.S.R.C.S. . . . . . . . . . 576

Reporting Deaths to the Coroner

J. D. J. Havard, M.D., LL.B............576

Fenfluramine and Psychosis

P. J. Shannon, M.B., and others . . . . . . 576

Aspirin and What Else?

E. P. Gétaz, M.R.C.P..............5576

Chemotherapy before Bowel Resection

D. W. Bracey, F.R.C.S..............576

Ghastly Abbreviations

J. D. Jackson, M.B.... . . . . . . . . . 577

Multiple Sclerosis and Malignant Gliomas

P. G. Lynch, M.R.C.PATH..............577

Standardization of the E.S.R.

R. J. M. Lane, M.B., and G. V. Gill, M.B. . . 577 Demand and the N.H.S.

J. W. Todd, F.R.C.P...............577

New Curriculum

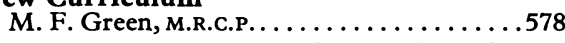

Appointment Systems in General Practice

D. W. Cammock, F.R.C.G.P..........578

Cleft Lip and Palate

Margaret Edwards, M.PHIL., L.C.S.T. . . . . . . . 578
Places in Medical Schools

T. Marshall, F.F.A.R.C.S. .

Twilight of the Medical Journal ?

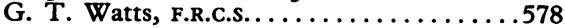

Price of a Consultation

A. Muir, L.R.C.P.ED... . . . . . . . . . 579

E.C.T. and Cardiac Arrythmia

S. M. Cannicott, M.B. . . . . . . . . . . 579

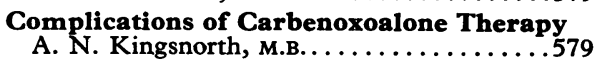

Rubella-specific IgM and a New Inhibitor

W. Al-Nakib, B.A., and others......... 579

Doctors' Pay

J. F. Nunn, F.F.A.R.C.s. . . . . . . . . . 579

Side Effect of Tranylcypromine

J. D. Wilson, M.B., D.P.M........... 580

Liver Hamartomas in Patients on Oral

Contraceptives
G. Vosnides, M.D., and others..........580

Nursing Staff and Work Load

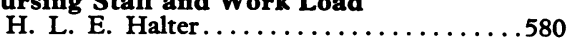

N.H.S. and the Profession

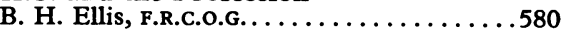

Finance and the Health Service

R. M. Milne. .....................580

N.H.S. Contraceptive Services

J. P. Lester, M.R.C.G.P............581
SIR,-Your leading article (27 July, p. 212) in some ways said what transfusion centre directors have been saying for many years. A document representing their unanimous opinions was submitted to the Department of Health and Social Security in September 1971. This recommended that the blood transfusion service should be reorganized round a uniform system of central administration and finance. In October 1972 a spokesman for the Department told directors that the comments and proposals in the document were unacceptable. We were disturbed by the Department's attitude and eventually, after strong representations, a revised version of our document was presented to the Standing Medical Advisory Committee of the Department in January 1973. In addition to presenting evidence in support of the need for reorganization the document requested that a working party be set up as a matter of urgency to examine the organization and administration of the National Blood Transfusion Service and to make recommendations.

Such a working party was formed later in 1973, and we hope that the Department will act on its recommendations and that these will result in an effective, national policy for the procurement and distribution of blood resources such as you suggest. One of the problems has been an apparent reluctance to appreciate that an administrative structure designed for running hospitals will not meet all the needs of a modern and expanding transfusion service. This attitude has created increasing difficulties since 1948. An essential element for success is the close $\infty$-ordination of the activities of the regional transfusion centres and the two central laboratories.
We in the transfusion service are well aware of its defects-and the remedies. We do not feel like lame ducks but more like wounded Drakes whose drums have been ignored for too long. Hence the present invasion of Spanish mercenaries from PuertoRico.-We are, etc.,

Regional Transfusion Centre, Cambridge

J. DARNBorough

Regional Transfusion Centre, Edgware

T. E. Cleghorn

F. STRATton

Regional Transfusion Centre,
Manchester

\section{Factors Influencing Neonatal Jaundice}

SIR,-We were interested in the findings of Dr. S. R. Gould and others (27 July, p. 228). We carried out a pilot retrospective study on the full-term infants admitted during 1973 to the special care unit of the Simpson Memorial Maternity Pavilion for neonatal hyperbilirubinaemia (criterion for selection an indirect serum bilirubin greater than 15 $\mathrm{mg} / 100 \mathrm{ml}$ venous blood). Despite the obvious drawbacks of such a study our findings showed: (1) no statistically higher rate of oral contraceptive usage among the mothers; (2) no clear relationship between jaundice and maternal oxytocin infusion or buccal pitocin administration; (3) the breast feeding rate was twice that of the normal hospital rate over the same period; (4) the Kielland forceps delivery rate in the jaundiced group was twice the mean for the hospital over the same period.

With respect to the first two points, we agree with Dr. Gould and his colleagues but on the third we tend to support the contention of Arthur et al.1 The differences, we think, may be related to the adequacy of fluid supplementation in the first few days of breast feeding. The fourth point has not been fully explained. Many centres have been impressed by the increase in neonatal jaundice in full-term infants and have tried to relate it to modern obstetric practice. We think that there are many factors but that one of them might be the trend towards inducing and shortening labour. Though totally commendable in terms of lower mortality the penalty may be delivery of a neonate not totally prepared for extrauterine life, including a conjugating system not yet triggered. There is obviously much to be learned in this field.

We are grateful to Professor J. O. Forfar and Dr. F. Cockburn for the use of data on patients under their care.-We are, etc.,

O. B. EDEN

\section{A. D. REVOLTA}

S. K. ADJEI

Simpson Memorial Maternity Pavilion,

Edinburgh

Arthur, L. J. H., et al., Developmental Medicine

SIR,-Dr. S. R. Gould and others (27 July, p. 228) show that maternal oxytocin infusion (Syntocinon) when used to expedite delivery does not influence neonatal jaundice. They conclude that these findings are contrary to those of our earlier study. 1

This is not an accurate reference to our findings. In this earlier study it was shown that bilirubin levels in infants of mothers whose onset of labour was spontaneous but 